\title{
Possible mechanisms of electrochemical processing activation ARMCO-iron
}

\author{
Konstantin Rakhimyanov ${ }^{1}$, Nadezhda Gaar $^{1, *}$, and Aleksandr Loktionov ${ }^{1}$ \\ ${ }^{1}$ Novosibirsk State Technical University, Faculty of Mechanical Engineering and Technologies, \\ 630073 Prospekt K. Marks 20, Novosibirsk, Russia
}

\begin{abstract}
The peculiarities of the electrochemical dissolving of ARMCOiron in the $15 \%$ water solution of the sodium chloride during electrochemical dissolving the material and under the impact of laser radiation with a wavelength of 1.06 micrometer are considered. The investigations were conducted at a special installation by the potentiodynamic method. It is established that the material passivation at a potential range of $1.26-2.6 \mathrm{~V}$ is observed during electrochemical dissolving the material in the stationary conditions. The increase in the value of the current density by 45 times occurs in introducing the laser radiation in the process of anode dissolving and the passivation areas are not observed. The dissolution process takes place actively in the whole range of potentials from 0 to $5 \mathrm{~V}$. It is shown that the main mechanisms of laser activation of electrochemical dissolving the materials is the depassivation of the anode surface and the acceleration of electrochemical reactions. It is determined that the maximum current density is achieved during laser-electrochemical processing of ARMCO-iron at a pulse repetition frequency of laser radiation equal to $3 \mathrm{kHz}$.
\end{abstract}

\section{Introduction}

The electrochemical processing based on anodic dissolving the material gained a wide application in the industry due to a high process productivity; the possibility of obtaining complex forms by using simple schemes of the tool and detail movement; the absence of any significant strength and temperature influence on the detail surface layer, which provides a high quality of processing. The independence of processing the material on their physical and mechanical properties determines the prospects of the electrochemical machining for the materials difficult to process. However, the formation of the films of different nature on the processed surface, which are hard to dissolve from the products of chemical reactions during the electrochemical processing, reduces the efficiency of electrochemical dissolution.

Nowadays there exist several methods of increasing the efficiency of the electrochemical processing: hydraulic and heat methods, the method of the reverse polarity, etc. However, the most perspective method of activation, from the standpoint of the possibility of realizing the complex of mechanisms is introducing the laser radiation in the

* Corresponding author: gaar@corp.nstu.ru 
inter-electrode gap between the cathode-tool and the anode-detail during the processing. A combined method was referred to as the laser-electrochemical size processing. From the theoretical point of view, the activation method allows implementing the main mechanisms of the activation process of the anode dissolving depending on the chosen combinations of the operating parameters of the laser radiation such as the wavelength, the frequency of pulse repetition frequency and the power density. It can increase the speed of the electrochemical processing practically for any metal [1, 2]. However, there exists the most effective mechanism of the activation process for every combination of the wavelength, the processed material and the chemical composition of the electrolyte. It can be found only from the experiments.

\section{Experimental data}

The laser electrochemical size processing proved its efficiency in processing different materials hard to process, namely, stainless steel, titanium alloys, tungsten-cobalt alloys [3 - 6]. A complicated chemical composition of the metals and alloys mentioned will mainly determine the peculiarities of the electrochemical dissolving during their processing. Because of this, it is desirable to determine the prevailing activation mechanisms of the laser electrochemical size processing on one-component or so-called "model" materials. ARMCO-iron was chosen as an investigated material in which the amount of iron in the chemical composition is $98 \%$. The water solution of the sodium chloride with a $15 \%$ concentration of salt was used as an electrolyte. This electrolyte composition is widely used in the electrochemical processing of iron-containing materials and meets the requirements for electrolytes used for the laser electrochemical processing [7]. The electrochemical cell and the installation for conducting experiments are described in detail in Papers [8] and [9], respectively. The installation allows conducting both electrochemical investigations of the material anode behavior in the stationary conditions (without radiation) and in the laser electrochemical processing. The investigations were conducted by using the wavelength of the laser radiation equal to 1.06 micrometer with the pulse repetition frequency from $2 \mathrm{kHz}$ to $4 \mathrm{kHz}$. The preliminary choice of the wavelength value and the pulse repetition frequency is based on the results of the preliminary experiments of the laser electrochemical size processing of iron-containing materials.

The average value of the power density of the laser radiation taking into consideration the extinction coefficient was equal to $3.3 \cdot 10^{3} \mathrm{~W} / \mathrm{m}^{2}$, which provided the absence of the electrolyte boiling in the zone of introducing the lased radiation according to the results of the mathematical calculations [10]. It was confirmed during the visual observation of the process.

The investigation of the material anode behavior was done by the polarization curves obtained in using the potentiodynamic method. The order of potential change and recording of the current value were accomplished by IPC-Pro M potentiostat-galvanostat in the potential sweep in the range from 0 to $5 \mathrm{~V}$ at a speed of $50 \mathrm{mV} / \mathrm{s}$

\section{Results of the research and discussion}

The polarization curve for ARMCO iron in the 15\% water solution of the sodium chloride obtained by the potentiodynamic method during the electrochemical processing (without the radiation) is presented in Figure 1. 


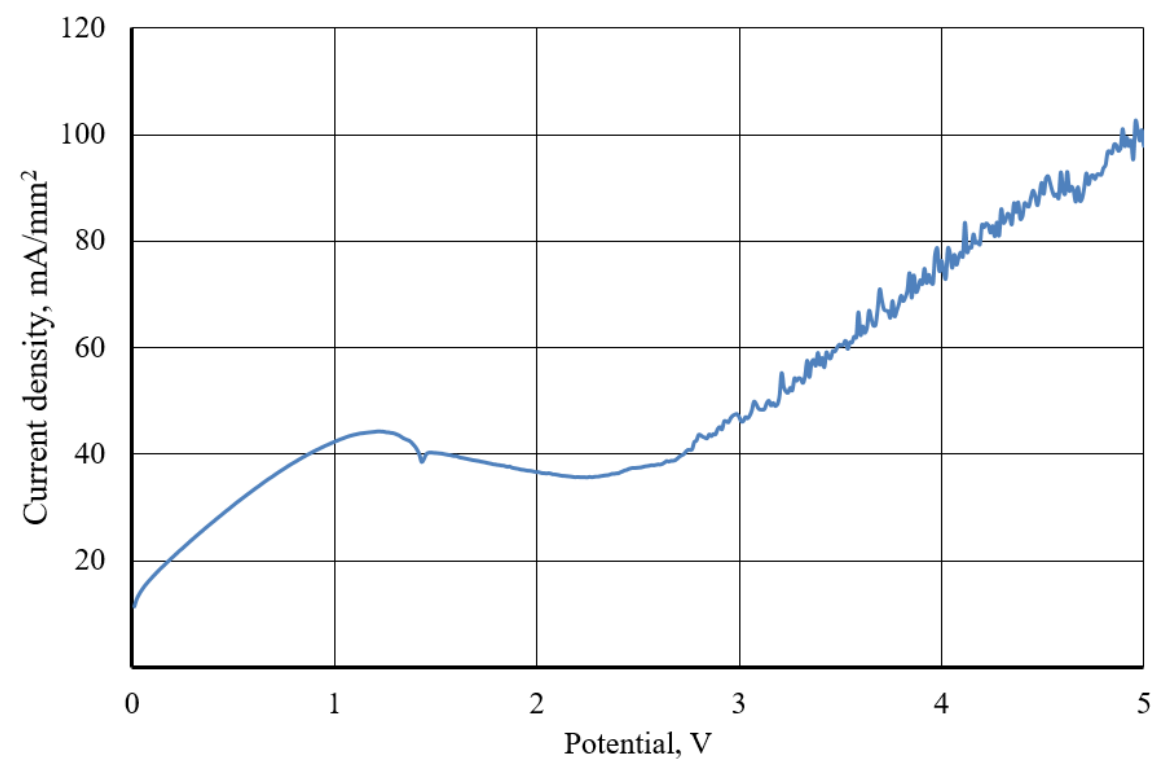

Fig. 1. Polarization curve obtained by the potentiodynamic method for ARMCO iron in $15 \%$ water solution of the sodium chloride during the electrochemical processing

Three specific areas can be identified on the polarization curve of the iron anode dissolving. The first area of the polarization curve is in the potential range from $-0.2 \mathrm{~V}$ to $1.25 \mathrm{~V}$ and is characterized by the increase in the current density with increasing the potential, which confirms the active dissolving of the processed material. The second area of the polarization curve possesses another character of dissolving and is in the potential range from $1.25 \mathrm{~V}$ to $2.6 \mathrm{~V}$. The fall in the current density with increasing the potential is observed in this area, which confirm the iron passivation. The next potential range (from $2.6 \mathrm{~V}$ to $5 \mathrm{~V}$ ) corresponds to the area with the growth in the current density in increasing the potential, which proves the active transpassive iron dissolution.

The polarization curve for ARMCO-iron in the $15 \%$ water solution of the sodium chloride obtained by the potentiodynamic method during the laser electrochemical size processing is presented in Figure 2.

The analysis of the polarization curve obtained during the laser electrochemical size processing shows that the use of laser radiation with a wavelength of 1.06 micrometer activates the process of electrochemical dissolving in the entire range of potential. In this case, the achieved values of the current density during the laser radiation is 45 times more than without it $\left(100 \mathrm{~mA} / \mathrm{mm}^{2}\right.$ and $4,500 \mathrm{~mA} / \mathrm{mm}^{2}$ for the $5 \mathrm{~V}$ potential). The oscillations of the current density observed during the laser electrochemical size processing are related to the intensive formation and removal of the gas bubbles from the sample surface. The electrolyte color during the laser electrochemical size processing changed more intensively than during the traditional electrochemical processing. Usually the change in the electrolyte color, connected with appearing the reaction products in the liquid, occurred during 5-8 experiments while the intensive change in color took place during one experiment in using the laser electrochemical size processing. It indicates the intensification of material electrochemical dissolving of the material in introducing the laser radiation in the processing zone. 


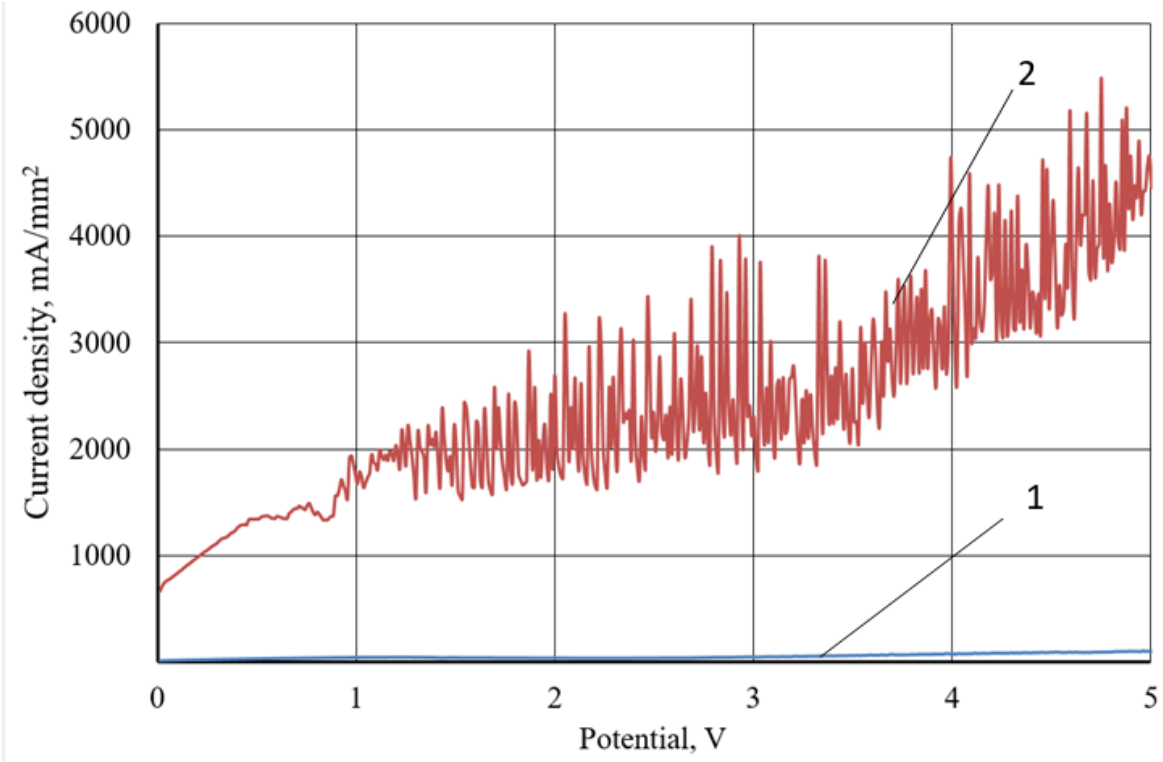

Fig. 2. Polarization curves obtained by the potentiodynamic method for ARMCO-iron in the $15 \%$ water solution of the sodium chloride: 1 - during the electrochemical processing; 2 - during the laser electrochemical size processing $\mathrm{c} \mathrm{f}=3 \mathrm{kHz}$

Decreasing the pulse repetition frequency below $3 \mathrm{kHz}(2 \mathrm{kHz}, 2.5 \mathrm{kHz})$ or increasing above $3 \mathrm{kHz}(3.5 \mathrm{kHz}, 4 \mathrm{kHz})$ led to the insignificant reduction in the achieved current density values. The decrease in the power density of the laser radiation from $3.3 \cdot 10^{3} \mathrm{~W} / \mathrm{m}^{2}$ also resulted in reducing the achieved current density values, but the character of the polarization curve remained the same.

Thus, the presence of the optimal value of the pulse repetition frequency allows suggesting that the light-hydraulic effect and the heat activation of the process are not considered as the main mechanisms of the activation process of material dissolving. If the main mechanism of activation were the light-hydraulic effect, the decrease in the pulse repetition frequency would be accompanied by increasing the current density. If the mechanism of the process heat activation prevails, the growth in the current density must be observed with increasing the pulse repetition frequency, which is not observed during the experiment. So, it is more probable that the main mechanisms of the laser activation of electrochemical dissolving of iron are the influence of radiation on the passivating films and the photoactivation of electrochemical dissolving.

\section{Conclusions}

The analysis of the polarization curves of ARMCO-iron anode dissolving during the electrochemical processing and the laser electrochemical size processing in $15 \%$ water solution of sodium chloride allows coming to the following conclusions:

1. The use of the laser radiation with a wavelength of 1.06 micrometer during the laser electrochemical size processing of ARMCO-iron in the water solution of the sodium chloride is effective. It allows increasing the current density by 45 times more than during the electrochemical processing. 
2. The pulse repetition frequency equal to $3 \mathrm{kHz}$ is optimal for the laser electrochemical size processing of ARMCO-iron from the viewpoint of the achieved values of the current density.

3. The most probable activation mechanisms of ARMCO-iron by the laser electrochemical size processing are the influence of radiation on the passivating films as well as the photoactivation of electrochemical dissolving.

\section{References}

1. J.A. McGeough, Principles of electrochemical machining. L.: Chapman and Hall, 1974 - 255 p.

2. Electrochemical machining/Eds. De Barr A. E., Oliver D.A. L.: Macdonald, 1968 - 248 p.

3. J. F. Wilson. Practice and theory of electrochemical machining. N.Y.: Wiley, 1971 $252 \mathrm{p}$.

4. A. D. Davydov, E. Kozak, Vysokoskorostnoye elektrokhimicheskoye formoobrazovaniye (High-speed electrochemical shaping), - Moscow: The science, 1990. - $272 \mathrm{p}$.

5. A. D. Davydov, V.M. Volgin, V. V. Lyubimov, Elektrokhimicheskaya razmernaya obrabotka metallov: protsess formoobrazovaniya (Electrochemical dimensional processing of metals: the process of shaping). Elektrokhimiya = Electrochemistry, 40, pp. 1438-1442 (2004) (in Russian).

6. V. S. Krylov, A. D. Davydov, Problemy teorii elektrokhimicheskogo formoobrazovaniya i tochnosti razmernoy elektrokhimicheskoy obrabotki (Problems in the theory of electrochemical shaping and the accuracy of dimensional electrochemical processing), Elektrokhimiya = Electrochemistry, 11, pp. 1115-1179 (1975) (in Russian).

7. Yu. N. Petrov, Osnovnyye napravleniya issledovaniy v oblasti EKhRO (The main areas of research in the field of EXPO). Elektrokhimicheskaya razmernaya obrabotka = Electrochemical dimensional processing. Kishinev: Shtiintsa, pp. 5-8 (1954) (in Russian).

8. Kh. M. Rakhimyanov, N. P. Gaar, Puti intensifikacii jelektrohimicheskoj razmernoj obrabotki (Ways for intensification of electrochemical dimensional machining), Polzunov's almanac, Barnaul, I.I. Polzunov Altai State Technical University, 4, pp. 191-192 (2008) (in Russian).

9. Kh.M. Rakhimyanov, N. P. Gaar, Possible ways for intensification of dimensional electrochemical machining (DECM). IFOST. Novosibirsk- Tomsk, Russia, June 23-29, 2008, Proceedings of the third international forum on strategic technologies, Novosibirsk, Novosibirsk State Technical University, pp. 106-107 (2008).

10. Kh. M. Rakhimyanov, K. Kh. Rakhimyanov, A. I. Zhuravlev, N. P. Gaar, A. A. Loktionov, Anodnoye povedeniye titanovogo splava marki OT-4 pri intensifikatsii lazernym izlucheniyem protsessa elektrokhimicheskogo rastvoreniya (Anodic behavior of titanium alloy OT-4 with electrochemical stripping in the conditions of laser influence), Obrabotka metallov (tekhnologiya, oborudovanie, instrumenty) = Metal Working and Material Science, 51, pp. 11-13 (2011) (in Russian).

11. Kh. M. Rakhimyanov, B. A. Krasilnikov, K. Kh. Rakhimyanov, A. I. Zhuravlev, N. P. Gaar, A. A. Loktionov, Elektrokhimicheskaya obrabotka tverdogo splava VK8 $v$ usloviyakh lazernogo vozdeystviya dlinoy volny $1.06 \mathrm{mkm} v$ khloride natriya 
(Dimensional electrochemical machining of firm alloy BK8 in the conditions of laser influence), Obrabotka metallov (tekhnologiya, oborudovanie, instrumenty) = Metal Working and Material Science, 50, pp. 3-7 (2011) (in Russian).

12. Kh. M. Rakhimyanov, B. A. Krasilnikov, N.P. Gaar, A. B. Sharapov, Anodnoe povedenie nerzhavejushhej stali 12H18N9T v uslovijah lazernoj aktivacii processa jelektrohimicheskoj razmernoj obrabotki (Anode behaviour of "12X18H9T" stainless steel in the conditions of laser activation of electrochemical dimensional machining process), Proceedings of the All-Russian Scientific Conference of Young Scientists "Science. Technology. Innovation", Dec. 3-5, Novosibirsk, Novosibirsk State Technical University, Part 2, pp. 262-264 (2010) (in Russian).

13. K. M. Rakhimyanov, N. P. Gaar, A. A. Loktionov, Role of laser radiation in activating anodic dissolution under electrochemical machining of metals and alloys, MATEC Web of Conferences. - Vol.129: International Conference on Modern Trends in Manufacturing Technologies and Equipment (ICMTMTE 2017). - Art. 01070 (4 p.). (2017) - DOI: $10.1051 /$ matecconf/201712901070.

14. Kh. M. Rakhimyanov, B. A. Krasilnikov, N. P. Gaar, A. I. Zhuravlev, A. A. Loktionov, Metodika vybora elektrolita dlya lazerno-elektrokhimicheskoy obrabotki (Method of selection electrolyte for laser-electrochemical treatment), Obrabotka metallov (tekhnologiya, oborudovanie, instrumenty) = Metal Working and Material Science, 55, pp. 18-21 (2012) (in Russian).

15. Kh. M. Rakhimyanov, N. P. Gaar, Jelektrohimicheskaja jachejka dlja issledovanija intensifikacii JeHRO lazernym izlucheniem (Electrochemical cell for investigation of DECM intensification by laser radiation), Proceedings of the first Russian ScientificTechnical Conference, Modern ways for machine-building and auto-transport development in Kuzbass, Oct. 24-25, Kemerovo, Kuzbass State Technical University, pp. 251-254 (2007) (in Russian).

16. Kh. M. Rakhimyanov, B. A. Krasilnikov, N. P. Gaar, A. I. Zhuravlev, A. A. Loktionov, Ustanovka dlya issledovaniya materialov $v$ usloviyakh lazernoelektrokhimicheskoy obrabotki kombinirovannym izlucheniyem (Installation for studying materials under of laser-electrochemical treatment combined radiation), Obrabotka metallov (tekhnologiya, oborudovanie, instrumenty) = Metal Working and Material Science, 56, pp. 30-32 (2012) (in Russian).

17. Kh. M. Rakhimyanov, N. P. Gaar, Matematicheskoe modelirovanie pri lazernoj termoaktivacii jelektrohimicheskoj razmernoj obrabotke (Mathematical simulaion during laser thermoactivation of electrochemical dimensional machining), Modern technological systems in machine-building (MTSM-2006). Collection of repots abstracts of international scientific-technical conference, Barnaul, I.I. Polzunov Altai State Technical University, pp. 45-47, (2006) (in Russian). 